\title{
Ontogenetic changes in habitat use by postlarvae and young juveniles of the blue crab
}

\author{
Renee A. Pardieck, Robert J. Orth*, Robert J. Diaz, Romuald N. Lipcius \\ The College of William and Mary, School of Marine Science, Virginia Institute of Marine Science, Gloucester Point, \\ Virginia 23062, USA
}

\begin{abstract}
Changing habitat requirements are evident during the developmental cycles of many species. In this field investigation, we attempted to distinguish between depth (shallow vs deep), habitat structure (seagrass species), and study site as factors influencing the distribution and abundance of postlarvae and juvenile blue crabs Callinectes sapidus in the Chesapeake Bay. Deep $(\geq 70 \mathrm{~cm}$ mean low water [MLW]) and shallow ( $\leq 50 \mathrm{~cm}$ MLW) suction samples in monospecific Zostera marina and Ruppia maritima beds were taken in the York River, a tributary of the Chesapeake Bay. Our studies revealed ontogenetic changes in habitat use, which suggested that blue crabs are influenced differently by physical and biological factors even during the earliest life stages. Postlarvae through 3rd instar distributions were not related to seagrass species, but their densities increased with distance upriver (regression, $\mathrm{p}<0.004, \mathrm{n}=36$ to 38 , postlarvae: $\mathrm{r}^{2}=0.173,1$ st instars: $\mathrm{r}^{2}=0.308$, 2nd -3 rd instars: $\mathrm{r}^{2}=$ 0.231 ). This suggests that the smallest instar distributions are related to larval supply and physical forces, such as currents and winds, which determine water-column transport. In contrast, 4th and greater instars were significantly more abundant in Ruppia than in Zostera (ANOVA, df $=1, \mathrm{p}<0.05$ ), possibly because of the high shoot density of Ruppia beds. Habitat use by 4 th and greater instars may be related to seasonal changes in seagrass shoot density. Water depth did not influence the distribution of any crab stage. We suggest that habitat selection and differential mortality among habitats influence larger instar distributions more strongly than they influence the distribution of postlarvae and the earliest instars of $C$. sapidus.
\end{abstract}

KEY WORDS: Blue crabs - Callinectes sapidus - Ontogenetic changes · Habitat structure $\cdot$ Habitat use - Settlement $\cdot$ Recruitment $\cdot$ Shallow-water refuge $\cdot$ Seagrass beds

\section{INTRODUCTION}

Distributions of marine organisms are often mediated by habitat complexity (Roughgarden et al. 1988, Olmi et al. 1990, Eggleston \& Armstrong 1995), which is defined by structural aspects of the environment, such as rock, heterogeneous sediments, oyster reefs, worm tubes, macroalgae and emergent or submersed vegetation (Marinelli \& Coull 1987, Day \& Lawton 1988, Wilson et al. 1990, Heck \& Crowder 1991, Schneider \& Mann 1991a, Love \& Bailey 1992). High organism abundances in complex habitats may be due to flow-induced transport (Eckman 1983, Eckman \& Nowell 1984, Butman 1987), reduced predation (decapod crustaceans, Heck \& Thoman 1981; spiny lobster, Hermkind \& Butler 1986, Lipcius et al. 19998; queen conch, Ray \& Stoner 1995; amphipods, Ryer 1987; Atlantic cod,

\footnotetext{
•Addressee for correspondence. E-mail: jjorth@vims.edu
}

Tupper \& Boutilier 1995), abundant living space, and food availability (snails, Bronmark 1985; amphipods, Hacker \& Steneck 1990; juvenile spiny lobster, Herrnkind \& Butler 1986; epifaunal invertebrates, Schneider \& Mann 1991b; juvenile blue crab, Perkins-Vissser et al. 1996).

Water depth can also affect species distributions. In simple, unstructured areas, many organisms take refuge in shallow water (Ruiz et al. 1993), where their predators (e.g. larger finfish or invertebrates) are less abundant. These primary predators may avoid shallow water because of their susceptibility to avian and mammalian predators higher in the food web, because of decreased foraging ability, or because of fluctuating temperature and oxygen levels (Ruiz et al. 1993, Loneragan et al. 1994, Dittel et al. 1995, Lonzarich \& Quinn 1995, Platell \& Potter 1996). Alternatively, high food abundances can attract both prey and predators into shallow water in some systems (Miltner et al. 1995). 
Interactions between depth and habitat complexity occur in some habitats. Plant species composition, leaf morphology, and the abundances of woody debris, shells and rooted submersed aquatic plants often change with depth (den Hartog 1977, Duarte 1991, Platell \& Potter 1996). In seagrass beds, habitat complexity and depth collectively influence species distributions. The high density and diversity of fauna associated with seagrass beds (Orth 1977, Orth et al. 1984, Heck et al. 1995) can vary within and between seagrass species (Schneider \& Mann 1991b). Measures of habitat complexity, such as plant biomass, blade density, leaf surface area, plant architecture, and plant species composition, may explain these patterns (Stoner 1980, 1983, Orth et al. 1984, Stoner \& Lewis 1985, Virnstein \& Howard 1987, Orth 1992, Lipcius et al. 1998). Seagrass beds also slow currents and enhance deposition of fine sediments and passive plankters. This effect varies with plant morphology, bed shape, size and height of different seagrass species (Kikuchi \& Peres 1977, Fonseca \& Fisher 1986) and may influence larval distributions (Orth 1992).

Given the many facets of habitat complexity and the limitations of space, food, or refugia in the marine environment, the distributions of many organisms shift during development. An obvious example is an organism, such as the blue crab, progressing from a planktonic to a benthic existence (Olmi et al. 1990). Such ontogenetic changes in habitat use can result from changing nutritional needs, competition, and predation. During development, the spiny lobster Panulirus argus shifts from plankton to macroalgae to crevices, and finally ventures into open spaces when it is large enough to deter predators (Childress \& Herrnkind 1994). In a laboratory experiment, small and medium Jonah crabs chose cobble substrate over sand more frequently and burrowed deeper than large crabs, compensating for their increased vulnerability to predation (Richards 1992). This investigation reveals subtle changes in the habitat use of blue crabs during the rapid growth of the earliest life stages.

In the Chesapeake Bay, 2 seagrass species with distinct morphologies and spatial distributions dominate shoal areas $(<2 \mathrm{~m}$ at mean low water [MLW]): widgeon grass Ruppia maritima (hereafter Ruppia)and eelgrass Zostera marina (hereafter Zostera). Vegetative Zostera has wide, straplike blades; reproductive Zostera, appearing from April to June in the Chesapeake Bay, has longer, branched shoots, each with several spathes (den Hartog 1970, Orth \& Moore 1986). In contrast, vegetative Ruppia has short, threadlike shoots. Reproductive Ruppia, growing mainly from July through September, has highly branched, threadlike shoots, which can reach over a meter in length. Ruppia commonly grows in monospecific stands in shallow water (approx. $<0.3 \mathrm{~m} \mathrm{MLW).} \mathrm{At} \mathrm{intermediate} \mathrm{depths}$ (approx. 0.3 to $0.6 \mathrm{~m} \mathrm{MLW),} \mathrm{Zostera} \mathrm{and} \mathrm{Ruppia} \mathrm{co-}$ occur, while in deep water (approx. > 0.6 m MLW), generally only Zostera is abundant (Orth \& Moore 1988).

Seagrass beds in the lower Chesapeake Bay are an important nursery habitat for the blue crab Callinectes sapidus (Orth \& van Montfrans 1987, Orth et al. 1996, Pile et al. 1996). After larval development on the continental shelf (Epifanio 1988), blue crab postlarvae reinvade the Chesapeake Bay and settle in seagrass beds, where growth through several juvenile stages occurs. The effectiveness of a seagrass bed as a refuge is a function of crab density (Perkins-Visser et al. 1996, Moksnes et al. 1997), crab size (Pile et al. 1996) and seagrass characteristics (Heck \& Thoman 1981, Williams et al. 1990, Schulman 1996). Postlarval settlement occurs episodically from July to November, with pulses associated with the full and new moons (van Montfrans et al. 1990, 1995).

Floral species composition and water depth are fundamental and ubiquitous features of the seagrass habitat, and likely influence survival, feeding and habitat preferences of blue crab postlarvae and young juveniles. Previous studies have not distinguished the effects of water depth and seagrass species on blue crab distributions, despite studies indicating that juveniles of epibenthic species should be more abundant in shallow (Ruiz et al. 1993), complex seagrass habitats (Humphries 1996). Also, blue crabs at different stages of growth could be influenced differently by physical and biological forces, even during the earliest stages of development. Hence, the objective of this study was to determine the effect of seagrass species and water depth on blue crab distributions, and examine ontogenetic changes in these distributions with respect to seagrass species and depth.

\section{STUDY SITES}

This investigation took place during the summers of 1994 and 1995, in the lower York River, within beds of Ruppia and Zostera (Fig. 1). Seagrasses were especially abundant along the north shore, from the river mouth to Gloucester Point. On the south shore, seagrasses were only abundant at the mouth. There were 2 types of seagrass beds: (1) monospecific Zostera beds in shallow and deep water (20 to $100 \mathrm{~cm}$ MLW), and (2) Ruppia/Zostera beds, in which monospecific Ruppia in the shallows ( $\leq 50 \mathrm{~cm}$ MLW) graded into monospecific Zostera at deeper depths ( $\geq 70 \mathrm{~cm}$ MLW). Only monospecific areas within Ruppia/Zostera beds were sampled (Fig. 2). Mixed beds were excluded from sampling. 
In 1994, reproductive and vegetative Ruppia were present during sampling. Reproductive Zostera defoliated prior to sampling in both 1994 and 1995, as did reproductive Ruppia in 1995 . In 1994, water temperature ranged between 21 and $28^{\circ} \mathrm{C}$. Salinity ranged between 12 and $22 \%$. On the north shore, Ruppia beds were in water depths from 15 to $48 \mathrm{~cm} \mathrm{MLW,} \mathrm{and}$ Zostera beds from 47 to $85 \mathrm{~cm}$ MLW. On the south shore, Ruppia beds were in water depths from 20 to $34 \mathrm{~cm} \mathrm{MLW}$, and Zostera beds from 25 to $59 \mathrm{~cm}$ MLW. In 1995 , sediments at the study sites were generally 80 to $90 \%$ sand and 10 to $20 \%$ silt and clays. Water temperature ranged between 20 and $25^{\circ} \mathrm{C}$. Salinity ranged between 20 and $25 \%$. Blue crab postlarvae recruit to the York River from mid-July to November (van Montfrans et al. 1990, 1995), where they settle in seagrass beds and grow through the early juvenile instars (Lipcius et al. 1990, Olmi et al. 1990, Orth et al. 1996).

\section{MATERIALS AND METHODS}

In 1994, we tested the hypothesis that early-stage blue crabs were evenly distributed between adjacent Ruppia and Zostera beds. A grid $(100 \times 100 \mathrm{~m})$ was established near the York River mouth on each shore: Guinea Marsh (north) and Goodwin Island (south)
(Fig. 1). Each grid enclosed approximately equal proportions of Ruppia in the shallows and Zostera in deeper areas. Mixed grassbeds in the center of the grids were excluded from sampling. Prior to sampling, grids were marked at $10 \mathrm{~m}$ intervals, resulting in 100 quadrats, each $10 \times 10 \mathrm{~m}$. On each sampling date, 20 quadrats were randomly selected from each grid: 10 each in Zostera and Ruppia areas.

As in previous summers, blue crab postlarval abundance was monitored in the York River with nightly plankton samples and artificial settlement substrates (van Montfrans et al. 1995). Our sampling was initiated on 26 July, 20 August, 23 August, 21 September, and 23 September, after postlarval pulses were detected. On all dates, samples were taken on each shore. Because of patchy seagrass beds and epiphyte growth, samples on the north shore in July were excluded from this study. Crabs were sampled with a suction dredge (Orth \& van Montfrans 1987) in each randomly selected grid unit. A $0.05 \mathrm{~m}^{2}$ drop cylinder was placed over the grass, and crabs were suctioned into a mesh bag for $30 \mathrm{~s}$. Spine to spine carapace width $(\mathrm{CW})$ of each crab was measured with calipers to the nearest $\mathrm{mm}$. In each selected grid, a $0.02 \mathrm{~m}^{2}$ core was used to sample above-ground standing seagrass crop. Aboveground wet weight and dry weight were determined for vegetative and reproductive Ruppia and vegetative



Fig. 1. Map of study area showing 1994 and 1995 sampling sites in seagrass beds in the York River, Virginia 
Monospecific Zostera Bed

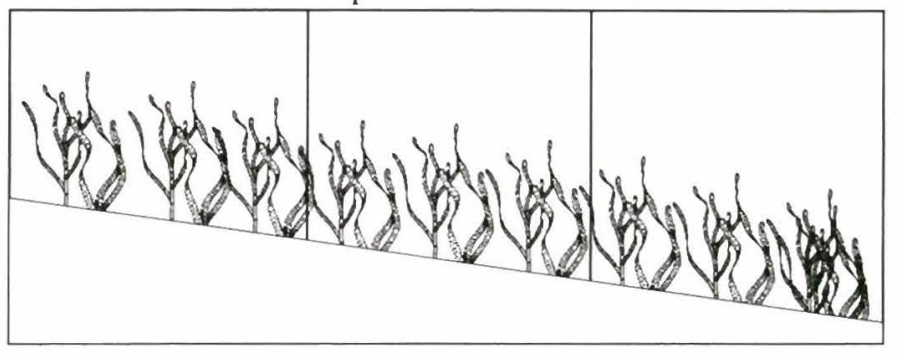

Ruppia / Zostera Bed

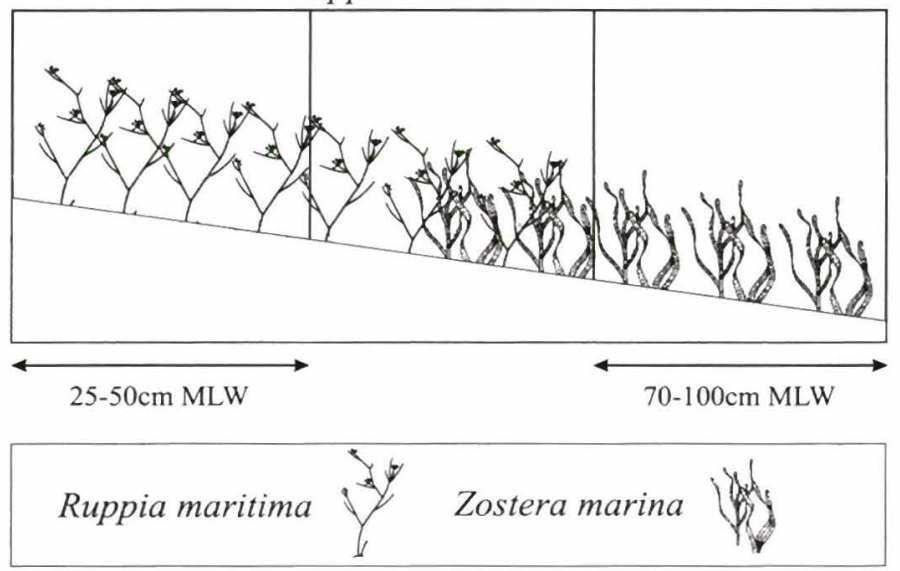

Fig. 2. Types of grassbeds found in the York River during the study period. Samples were taken at shallow and deep depths in monospecific grassbeds. Mixed areas, at intermediate depths, were excluded from sampling

Zostera collected in core samples. For wet weights, above-ground material was separated from roots and rhizomes, and then weighed to the nearest $0.0001 \mathrm{~g}$ on an electric balance. Plants were then dried at $75^{\circ} \mathrm{C}$ for at least $48 \mathrm{~h}$, and then reweighed to determine dry weights. Temperature, water depth and salinity were measured for each plant and crab sample.

Blue crabs were grouped into 3 size classes: postlarvae and 1st instars $(<3.1 \mathrm{~mm} \mathrm{CW}), 2$ nd to 5 th instars (3.1 to $9.1 \mathrm{~mm} \mathrm{CW})$, and larger juveniles $(>9.1 \mathrm{~mm}$ CW) (Pile et al. 1996). Crabs could not be grouped into finer divisions because of low crab densities. The effect of size class on the odds of settling in Ruppia over Zostera was evaluated using logistic regression (Agresti 1990). We assumed that within a size class, each crab was an independent replicate, and binary responses were between Ruppia and Zostera habitats. The assumption of independence for each crab was justified by the general lack of aggregation, determined by a goodness-of-fit test to a Poisson series (for each crab size class, in July, August and September, in Ruppia or Zostera, on the north or south shore) (Elliott 1971). Most areas contained randomly distributed crabs according to this test $(Q=0.975, \mathrm{df}=8,9$, or 19 , $\mathrm{p}>0.05$ ) (Pearson \& Hartley 1966). A contagious distri- bution was only found in August, for 2nd to 5th instars on the south shore (Ruppia: $Q=0.975$, df $=19, \mathrm{p}<0.05$; Zostera: $Q=0.975, \mathrm{df}=19, \mathrm{p}<$ $0.05)$, and in September, for postlarvae to $1 \mathrm{st}$ instars on the north shore in Ruppia beds $(Q=$ 0.975, df $=19, \mathrm{p}<0.05$ ).

The predicted $\mathrm{p}$ of a crab occurring in Ruppia was obtained from the logistic function derived from the logistic regression. The predicted $p$ for crab occurrence in Zostera was 1 - p. On the north and the south shore, the probability of occurrence of each crab was compared between Ruppia and Zostera through time. Crab densities in Ruppia and Zostera were significantly different if a $95 \%$ confidence interval generated from the asymptotic standard error excluded a probability of 0.5 , which denotes even proportions of crabs in each treatment (Agresti 1990).

The 1994 results indicated that seagrass species, depth, or site were influencing crab distributions, but we could not distinguish between these effects since grass species covaried with water depth. In 1995, because of unusually extreme summer leaf defoliation, grassbeds were too sparse on the south shore to continue inquiries into the shore effect. Therefore, in 1995, we attempted to distinguish effects of seagrass species and depth on juvenile blue crab distributions and examine ontogenetic changes in habitat use on the north shore. As described previously, bed types were classified into monospecific Zostera beds and Ruppia/Zostera beds (with monospecific Ruppia in the shallows adjacent to monospecific Zostera in deeper water) (Fig. 2). Deep (70 to $100 \mathrm{~cm} \mathrm{MLW)} \mathrm{and} \mathrm{shallow}$ ( 25 to $50 \mathrm{~cm} \mathrm{MLW)} \mathrm{sites} \mathrm{were} \mathrm{randomly} \mathrm{selected} \mathrm{in}$ Zostera beds and in Ruppia/Zostera beds, resulting in 4 treatments: deep and shallow Zostera beds, and deep and shallow Ruppia/Zostera beds (Fig. 1). The shallow Ruppia/Zostera treatment only contained Ruppia, whereas the remaining 3 treatments only contained Zostera. Mixed beds were excluded from sampling. Randomly selected sites were marked with stakes prior to sampling, which was initiated after peaks in postlarval settlement were detected with plankton samples and settlement substrates (J. van Montfrans unpubl. data). Four suction samples were taken at randomly selected sites in each treatment on each of 3 consecutive days: 8 to 10 October, using a $1.67 \mathrm{~m}^{2}$ sampling ring. The ring was deployed next to the field marker, and the enclosed contents were suctioned for $6 \mathrm{~min}$, followed by $3 \mathrm{~min}$ of dipnetting. This method has an $88 \%$ efficiency in crab capture in seagrass beds (Orth \& van Montfrans 1987). Before sampling crabs, plant biomass cores $\left(0.02 \mathrm{~m}^{2}\right)$ were taken inside each sampling ring to determine above-ground 
dry weight, shoot density and canopy height of vegetative Ruppia and vegetative Zostera. Sediment cores were taken with all samples and frozen for later analysis. Temperature, salinity, and depth were also recorded.

Blue crabs were grouped into 6 size classes for analyses: postlarvae, 1 st instars $(<3.1 \mathrm{~mm} \mathrm{CW}), 2$ nd to 3rd instars ( 3.1 to $5.9 \mathrm{~mm}$ ), 4th to 7 th instars (6.0 to $12.6 \mathrm{~mm})$, 8th to 9th instars $(12.7$ to $16.0 \mathrm{~mm})$ and greater than 9th instars (>16.0 mm) (Pile et al. 1996). Samples were analyzed by ANCOVA (dependent variable: crab density; independent variables: bed type and depth; blocked factor: date; covariates: grass dry weight, shoot density, log of shoot density, canopy height, distance upriver). Data were tested for homogeneity of variances and log-transformed when necessary. Linear regressions were conducted when covariates were significant (Zar 1984). Plant dry weight and shoot density were similarly tested as dependent variables by bed type and depth.

\section{RESULTS}

\section{Seagrass and algal composition 1994}

Although sampling grids were established in monospecific stands of the respective seagrass beds, some samples contained small amounts of the other grass species. Also, vegetation in some samples was covered by red algae, e.g. Ceramium spp. (E. Bailey pers. comm.), which was especially difficult to remove from the fine Ruppia shoots. Red algae made up a large proportion of many Ruppia samples. Red algae also grew on Zostera, but was easy to remove. Thus, comparisons of seagrass biomass are made tentatively. Ruppia dry weight averaged $15.3 \mathrm{~g} \mathrm{~m}^{-2}$. Zostera dry weight averaged $12.2 \mathrm{~g} \mathrm{~m}^{-2}$. In Ruppia-dominated beds, Ruppia biomass decreased through time on both shores, and Zostera decreased on the south shore. In Zostera-dominated beds, Zostera did not appear to change over time (Fig. 3). Algal biomass was not quantified.

\section{Differential habitat utilization}

In 1994, on the south shore, all crab stages were evenly distributed between Zostera and Ruppia, with 1 exception (Fig. 4). In August, crabs greater than the 5th instar were significantly more abundant in Ruppia than in Zostera $(\mathrm{p}<0.05)$.

On the north shore, all crab stages were significantly more abundant in Ruppia than in Zostera ( $\mathrm{p}<$ 0.05), except in August, when postlarvae and 1st instars were evenly distributed between Ruppia and Zostera (Fig. 4).

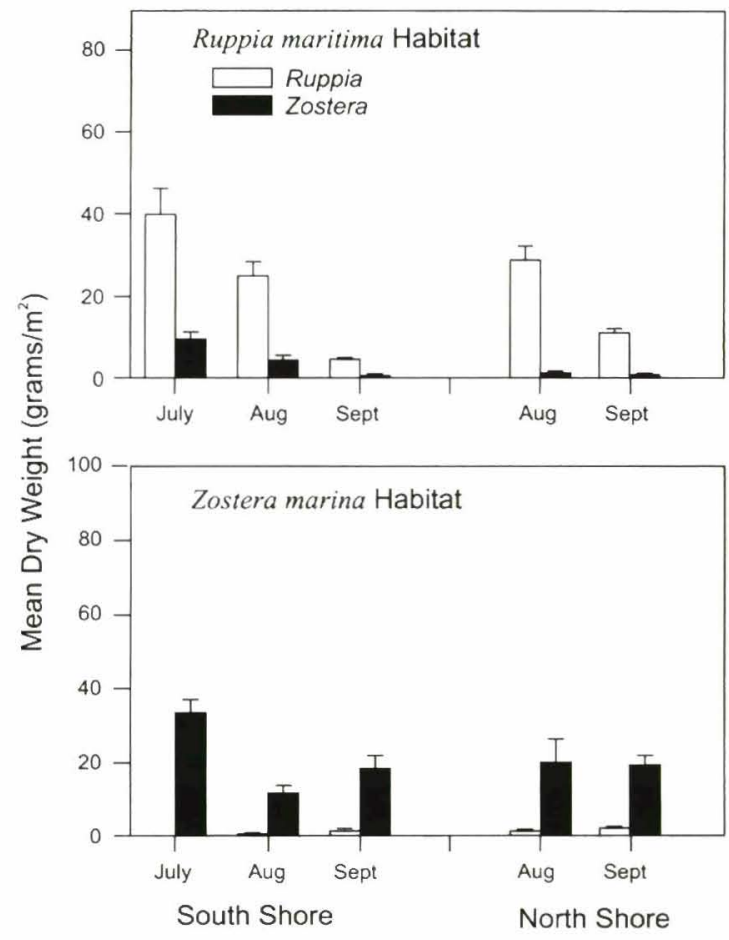

Fig. 3. Mean grass dry weights in Ruppia and Zostera habitats on the north and south shores of the York River in 1994. Standard error bars are shown

\section{Seagrass and algal composition 1995}

Seagrass dry weight and shoot density varied by bed type and depth (Table 1, Fig. 5). Ruppia dry weight averaged $20.1 \mathrm{~g} \mathrm{~m}^{-2}$ (shallow Ruppia/Zostera), and Zostera dry weight averaged $7.8 \mathrm{~g} \mathrm{~m}^{-2}$ (deep Ruppia/Zostera, deep and shallow Zostera beds). Shoot density averaged 3062 shoots $\mathrm{m}^{-2}$ for Ruppia and 220 shoots $\mathrm{m}^{-2}$ for Zostera. Grass dry weight was significantly greater in shallow Ruppia beds than in shallow or deep Zostera beds. Grass dry weight also was significantly greater in deep than in shallow Zostera beds. There were significantly more shoots in shallow Ruppia beds than in deep or shallow Zostera beds (Table 2, Fig. 5). There was no noticeable epiphyte growth on vegetation in 1995.

\section{Ontogenetic differences in habitat use}

Postlarvae through 3rd instars showed similar results by bed type, depth, and distance upriver (Table 3 , Figs. 6 \& 7). Crab densities averaged $2.0 \mathrm{~m}^{-2}$ (postlarvae), $6.8 \mathrm{~m}^{-2}$ (1st instars), and $3.4 \mathrm{~m}^{-2}$ (2nd to 3rd instars). Postlarvae, 1st instar, and 2nd to 3rd instar abundances did not vary by bed type or depth, and were not influenced by grass dry weight or shoot den- 

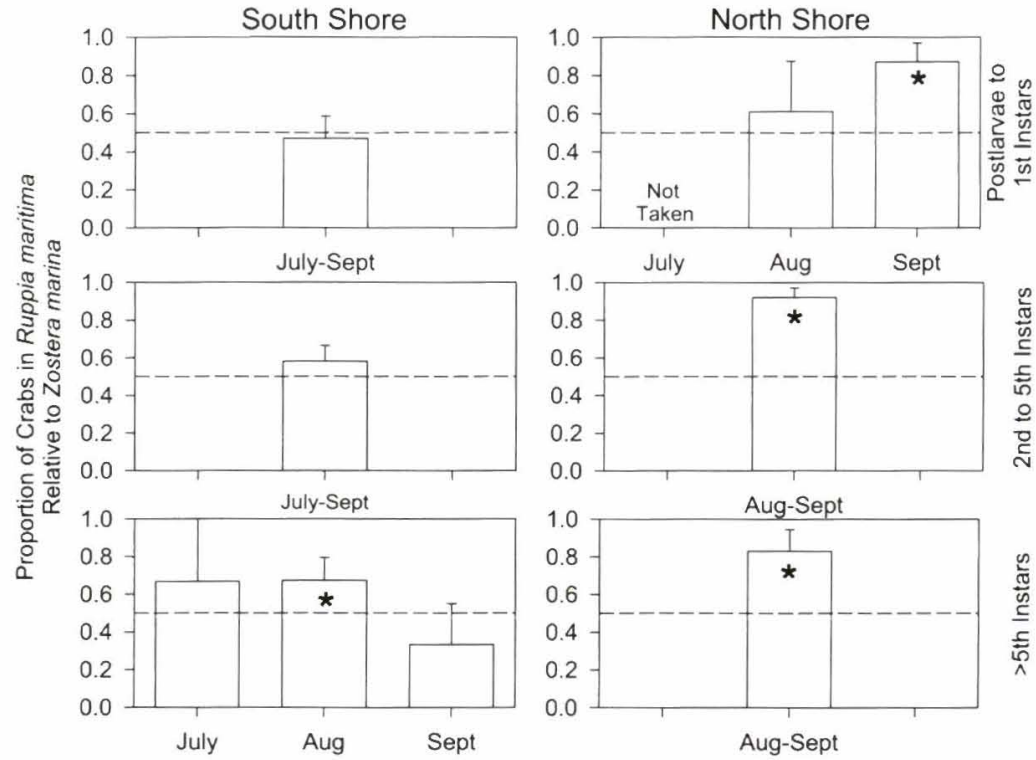

Fig. 4. Comparison of observed crab densities between Ruppia and Zostera on the north or south shore of the York River in 1994. Crabs are evenly distributed between Ruppia and Zostera if standard error bar overlaps line drawn at 0.5 . If proportions exceed 0.5 , crab densities are higher in Ruppia. If proportions are below 0.5, crab densities are higher in Zostera. ${ }^{\star}$ Significant differences between crab densities in Ruppia and Zostera $(p<0.05)$. When there is no significant change through time, crab proportions are collapsed across time and represented by a single bar

sity (Table 3, Fig. 6). In contrast, abundances of the earliest stages increased significantly with distance upriver (Table 3, Fig. 7), though with high variance.

Seagrass species strongly influenced distributions of crabs greater than the 3rd instar, with highest crab abundances in Ruppia habitats (Table 3, Fig. 6). Specifically, 4 th to 7 th instars were significantly more abundant in shallow Ruppia than in all other habitats (Zostera) (Table 4). In Ruppia/Zostera beds, 8th to 9th instar abundance was significantly higher in shallow Ruppia than in deep Zostera habitats (Table 4). 9th instars and greater were significantly more abundant in Ruppia/Zostera beds than in monospecific Zostera beds regardless of depth (Table 3), and highest abundances occurred in Ruppia beds. Depth appears to be unimportant in vegetated habitats since it was nonsignificant in monospecific Zostera beds, and only significant in Ruppia/Zostera beds, where it was tied to seagrass species. The covariates grass dry weight, shoot density, logtransformed shoot density, and distance upriver, were nonsignificant for crabs greater than the 3rd instar (Table 3).

Although the covariate shoot density was nonsignificant in all tests, late stage crab densities reflect this distinguishing seagrass characteristic (see above). In general, highest abundances of 4 th instars and greater occurred in shallow Ruppia beds which had the highest shoot densities. Ruppia shoot densities, which ranged between 700 and 4800 shoots $\mathrm{m}^{-2}$, were correlated with the number of 4 th to 7 th instars (regression, $\mathrm{r}^{2}=0.303$, $p=0.064$ ) (Fig. 8). Shoot density in Zostera beds, which ranged from 50 to 550 shoots $\mathrm{m}^{-2}$, was not significantly related to crab abundance.

\section{DISCUSSION}

Habitat use by blue crabs changes ontogenetically in seagrass beds and unvegetated habitats (Orth \& van Montfrans 1987). In our study, postlarvae and earliest instar distributions were related to site rather than seagrass species or water depth in shallow habitats (i.e. $<2 \mathrm{~m}$ depth). In contrast, 4 th and greater instar distributions were related to seagrass species, whereas water depth was not influential.

Table 1. ANOVA results with total dry weight or shoot density per $1.67 \mathrm{~m}^{2}$ as the dependent variable, bed type (B) and water depth (D) as fixed factors, and date as a blocking factor. ${ }^{*} p<0.05, \cdots \cdot p<0.0001$; ns: $p>0.05$

\begin{tabular}{|c|c|c|c|c|c|}
\hline & Factor & df & SS & MS & $F$ \\
\hline \multirow{4}{*}{ Total dry weight } & Bed type & 1 & 0.0814 & 0.0977 & $4.43^{\circ}$ \\
\hline & Depth & 1 & 0.0154 & $<0.0001$ & $<0.01 \mathrm{~ns}$ \\
\hline & $\mathrm{B} \times \mathrm{D}$ & 1 & 0.082 & 0.0812 & $3.68 \mathrm{~ns}$ \\
\hline & Date & 2 & 0.0426 & 0.0213 & $0.97 \mathrm{~ns}$ \\
\hline \multirow[t]{4}{*}{ Shoot density } & Bed type & 1 & 6664.2 & 5160.9 & $20.19 \cdots$ \\
\hline & Depth & 1 & 9602.5 & 4395.6 & $20.6 \cdots$ \\
\hline & $\mathrm{B} \times \mathrm{D}$ & 1 & 5499.5 & 5238.9 & $24.55 \cdots$ \\
\hline & Date & 2 & 638.7 & 319.4 & $1.5 \mathrm{~ns}$ \\
\hline
\end{tabular}


Table 2. Tukey's test for significant interaction effects between depth and bed type in ANOVA (Table 1). R-Z: Ruppia/Zostera beds; Z-Z: monospecific Zostera beds. To be conservative, we used $\mathrm{p}<0.1$ as the criterion for performing multiple comparison tests. Parentheses enclose mean dry weight and shoot density of each treatment combination

\begin{tabular}{|c|c|c|c|c|c|}
\hline & Category & Factor & & & Tukey's difference $^{a}$ \\
\hline \multirow[t]{6}{*}{ Dry weight } & \multicolumn{5}{|l|}{ Bed type } \\
\hline & $\mathrm{R}-\mathrm{Z}$ & Depth & $\begin{array}{l}\text { Deep } \\
(0.18)\end{array}$ & $\begin{array}{c}\text { Shallow } \\
(0.40)\end{array}$ & $0.218^{*}$ \\
\hline & $\mathrm{Z}-\mathrm{Z}$ & Depth & $\begin{array}{l}\text { Deep } \\
(0.17)\end{array}$ & $\begin{array}{c}\text { Shallow } \\
(0.11)\end{array}$ & $0.059 \cdots$ \\
\hline & \multicolumn{5}{|l|}{ Depth } \\
\hline & Shallow & Bed type & $\begin{array}{c}Z-Z \\
(0.11)\end{array}$ & $\begin{array}{c}R-Z \\
(0.40)\end{array}$ & $0.287^{\cdots}$ \\
\hline & Deep & Bed type & $\begin{array}{c}\mathrm{R}-\mathrm{Z} \\
(0.18)\end{array}$ & $\begin{array}{c}Z-Z \\
(0.17)\end{array}$ & $0.010 \mathrm{~ns}$ \\
\hline \multirow[t]{6}{*}{ Shoot density } & \multicolumn{5}{|l|}{ Bed type } \\
\hline & $\mathrm{R}-\mathrm{Z}$ & Depth & $\begin{array}{l}\text { Deep } \\
(1.64)\end{array}$ & $\begin{array}{c}\text { Shallow } \\
(2.79)\end{array}$ & $1.161 *$ \\
\hline & $\mathrm{Z}-\mathrm{Z}$ & Depth & $\begin{array}{l}\text { Deep } \\
(1.66)\end{array}$ & $\begin{array}{c}\text { Shallow } \\
(1.63)\end{array}$ & $0.037 \mathrm{~ns}$ \\
\hline & \multicolumn{5}{|l|}{ Depth } \\
\hline & Shallow & Bed type & $\begin{array}{c}Z-Z \\
(1.63)\end{array}$ & $\begin{array}{c}\mathrm{R}-\mathrm{Z} \\
(2.79)\end{array}$ & $1.161 \cdots$ \\
\hline & Deep & Bed type & $\begin{array}{c}\mathrm{R}-\mathrm{Z} \\
(1.64)\end{array}$ & $\begin{array}{c}\mathrm{Z}-\mathrm{Z} \\
(1.66)\end{array}$ & $0.020 \mathrm{~ns}$ \\
\hline
\end{tabular}

\section{Influence of site on postlarvae and earliest instar distributions}

Postlarvae detect and respond to chemical cues from Zostera and estuarine water (Forward et al. 1994) and can swim up to $12.6 \mathrm{~cm} \mathrm{~s}^{-1}$ (Luckenbach \& Orth 1992). Hence, they could hypothetically select between different seagrass habitats at low to moderate current speeds. In our study, however, earliest instar abundances (postlarvae through 3rd instars) differed between grass species (i.e. Ruppia and Zostera) in only 1 instance. Generally, earliest instars (postlarvae through 3rd instars) were not significantly influenced by bed type or depth, but differed significantly by site, increasing with distance upriver. This finding suggests that physical forces, rather than microhabitat characteristics, strongly influence early instar distributions. For instance, postlarvae apparently use onshore winds and currents to reinvade estuaries (Goodrich et al. 1989, Olmi 1994). Our findings are therefore consistent with the hypothesis that fine-scale habitat selection by blue crab postlarvae does not occur during water column transport, and that early stage distributions are mainly a function of larval supply and transport.
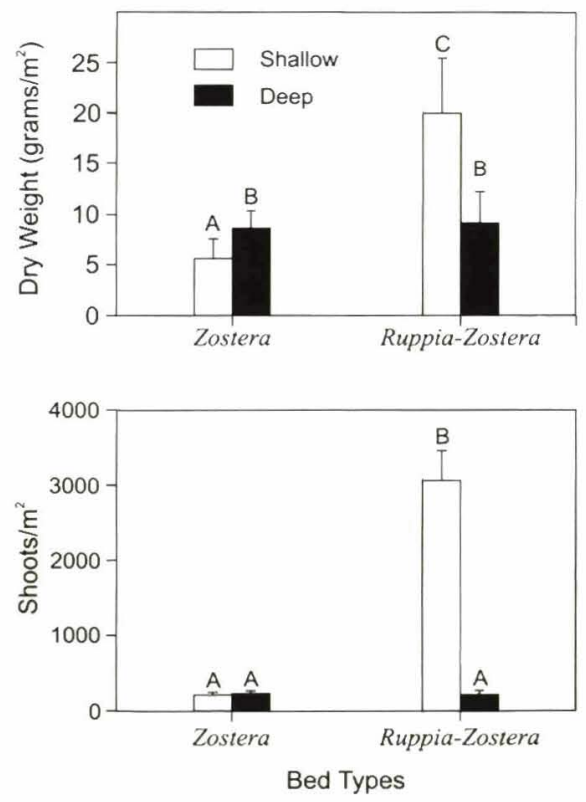

Fig. 5. Seagrass dry weight and shoot density at different depths and bed types in 1995. In Ruppia-Zostera beds, values are for Ruppia in the shallows and for Zostera in the deeper locations. Letters depict significant differences calculated from Tukey's test $(p<0.05)$ : bars sharing the same letters indicate nonsignificance 
Table 3. ANCOVA results by stage, with crab density per $1.67 \mathrm{~m}^{2}$ as the dependent variable, bed type and water depth as fixed factors, and date as a blocking factor. Distance upriver, grass dry weight, number of grass shoots, and canopy height were tested as covariates. Distance upriver was the only significant covariate. Nonsignificant covariates $(p>0.05)$ were removed from the models and results are not shown. $" p<0.05, \cdots p<0.01, \cdots p<0.005, \cdots p<0.0001 ; n s: p>0.05$

\begin{tabular}{|c|c|c|c|c|c|}
\hline & Factor & df & SS & MS & $F$ \\
\hline \multirow[t]{5}{*}{ Postlarvae } & Bed type & 1 & 13.69 & 10.76 & $1.09 \mathrm{~ns}$ \\
\hline & Depth & 1 & 10.78 & 9.14 & $0.93 \mathrm{~ns}$ \\
\hline & $\mathrm{B} \times \mathrm{D}$ & 1 & 9.57 & 9.72 & $0.99 \mathrm{~ns}$ \\
\hline & Date & 2 & 2.92 & 1.46 & $0.15 \mathrm{~ns}$ \\
\hline & Distance upriver & 1 & 61.7 & 60.59 & $6.14^{\circ}$ \\
\hline \multirow[t]{5}{*}{ 1st instars } & Bed type & 1 & 0.14 & 1.39 & $0.03 \mathrm{~ns}$ \\
\hline & Depth & 1 & 72.0 & 100.3 & $2.29 \mathrm{~ns}$ \\
\hline & $\mathrm{B} \times \mathrm{D}$ & 1 & 8.01 & 0.01 & $<0.01 \mathrm{~ns}$ \\
\hline & Date & 2 & 366.4 & 183.2 & $4.18^{\circ}$ \\
\hline & Distance upriver & 1 & 572.0 & 362.3 & $8.26^{*}$ \\
\hline \multirow[t]{5}{*}{$2 \mathrm{nd}-3 \mathrm{rd}$ instars ${ }^{\mathrm{a}}$} & Bed type & 1 & 0.61 & 0.42 & $0.75 \mathrm{~ns}$ \\
\hline & Depth & 1 & 0.13 & 0.44 & $0.78 \mathrm{~ns}$ \\
\hline & $\mathrm{B} \times \mathrm{D}$ & 1 & 0.95 & 0.74 & $1.31 \mathrm{~ns}$ \\
\hline & Date & 2 & 1.28 & 0.64 & $1.14 \mathrm{~ns}$ \\
\hline & Distance upriver & 1 & 5.26 & 3.52 & $6.26^{\circ}$ \\
\hline \multirow[t]{4}{*}{4 th -7 th instars ${ }^{a}$} & Bed type & 1 & 1.19 & 0.98 & $11.92 \cdots$ \\
\hline & Depth & 1 & 1.77 & 0.95 & $11.50 \cdots$ \\
\hline & $\mathrm{B} \times \mathrm{D}$ & 1 & 1.5 & 1.39 & $16.90 \cdots$ \\
\hline & Date & 2 & 0.15 & 0.08 & $0.91 \mathrm{~ns}$ \\
\hline \multirow[t]{4}{*}{ 8th-9th instars ${ }^{\mathrm{a}}$} & Bed type & 1 & 0.11 & 0.04 & $0.49 \mathrm{~ns}$ \\
\hline & Depth & 1 & 1.08 & 0.73 & $8.07^{\cdots}$ \\
\hline & $\mathrm{B} \times \mathrm{D}$ & 1 & 0.31 & 0.28 & $3.12 \mathrm{~ns}$ \\
\hline & Date & 2 & 0.07 & 0.04 & $0.40 \mathrm{~ns}$ \\
\hline \multirow[t]{4}{*}{$>9$ th instars ${ }^{\mathrm{a}}$} & Bed type & 1 & 0.56 & 0.57 & $6.11^{\circ}$ \\
\hline & Depth & 1 & 0.26 & 0.21 & $2.23 \mathrm{~ns}$ \\
\hline & $B \times D$ & 1 & 0.09 & 0.14 & $1.53 \mathrm{~ns}$ \\
\hline & Date & 2 & 0.29 & 0.15 & $1.58 \mathrm{~ns}$ \\
\hline
\end{tabular}

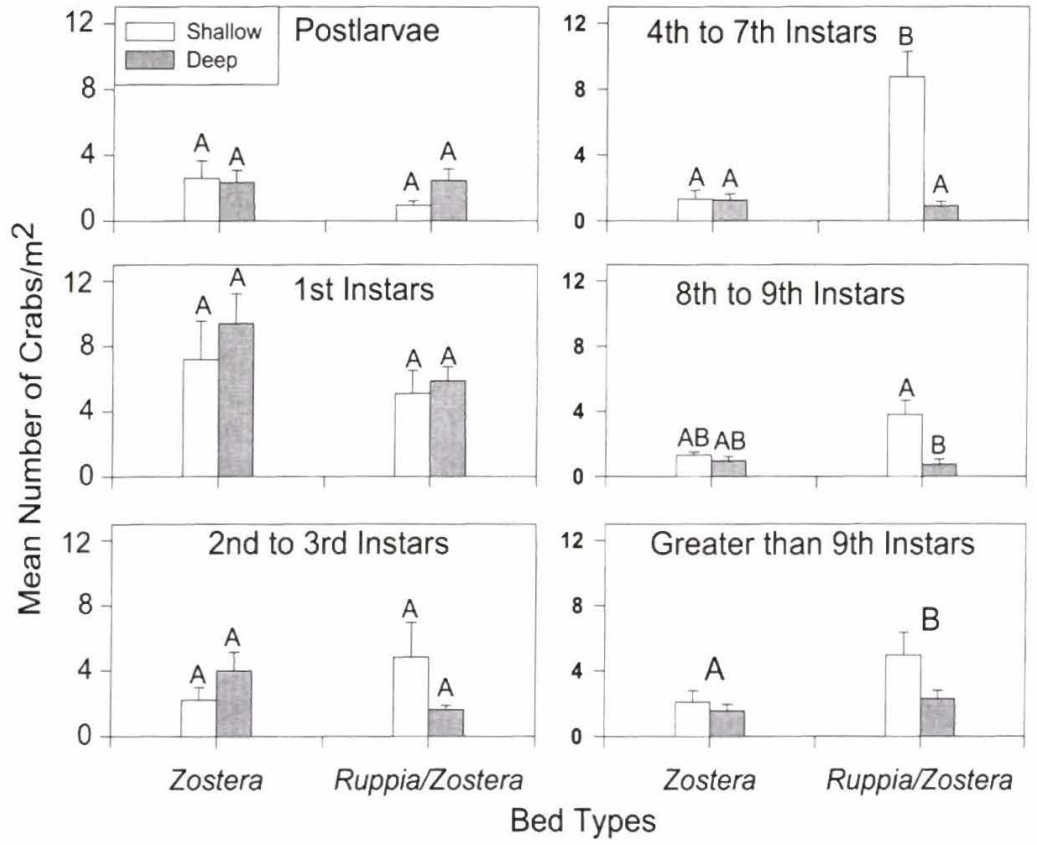

One explanation for the lack of microhabitat selection by early instars is cannibalism by larger conspecifics, which are abundant in shallow Ruppia beds. Similarly, in oyster shell habitats, early cohorts of the Dungeness crab Cancer magister reduced the density of subsequent cohorts through cannibalism or competition (Fernandez et al. 1993, Eggleston \& Armstrong 1995). Crab density patterns may have also reflected a postlarval pulse moving up the York River: sam-

Fig. 6. Mean number of crabs by depth and bed type in 1995. In Ruppia/Zostera beds, values are for Ruppia in the shallows and for Zostera in the deeper locations. Standard error bars are shown. Letters depict significant differences calculated from ANCOVA and Tukey's test $(p<0.05)$ : bars sharing the same letters indicate nonsignificance 
Table 4. Tukey's test for significant interaction effects between depth and bed type in ANCOVA (Table 3). R-Z: Ruppia/Zostera beds; Z-Z: monospecific Zostera beds. To be conservative, we used $p<0.1$ as the criterion for performing multiple comparison tests. Parentheses enclose mean densities of each treatment combination. ${ }^{\prime} \mathrm{p}<0.01, \mathrm{~ns}: \mathrm{p}>0.05$

\begin{tabular}{|c|c|c|c|c|c|}
\hline & Category & Factor & & & Tukey's difference \\
\hline \multirow[t]{6}{*}{4 th -7 th instars } & \multicolumn{5}{|l|}{ Bed type } \\
\hline & $\mathrm{R}-\mathrm{Z}$ & Depth & $\begin{array}{l}\text { Deep } \\
(0.33)\end{array}$ & $\begin{array}{c}\text { Shallow } \\
(1.12)\end{array}$ & $0.790 \cdots$ \\
\hline & $\mathrm{Z}-\mathrm{Z}$ & Depth & $\begin{array}{l}\text { Deep } \\
(0.40)\end{array}$ & $\begin{array}{c}\text { Shallow } \\
(0.41)\end{array}$ & $0.009 \mathrm{~ns}$ \\
\hline & \multicolumn{5}{|l|}{ Depth } \\
\hline & Shallow & Bed type & $\begin{array}{c}Z-Z \\
(0.41)\end{array}$ & $\begin{array}{c}\mathrm{R}-\mathrm{Z} \\
(1.12)\end{array}$ & $0.711^{\cdots}$ \\
\hline & Deep & Bed type & $\begin{array}{c}\mathrm{R}-\mathrm{Z} \\
(0.33)\end{array}$ & $\begin{array}{c}Z-Z \\
(0.40)\end{array}$ & $0.070 \mathrm{~ns}$ \\
\hline \multirow[t]{6}{*}{8 th -9 th instars } & \multicolumn{5}{|l|}{ Bed type } \\
\hline & $\mathrm{R}-\mathrm{Z}$ & Depth & $\begin{array}{l}\text { Deep } \\
(0.24)\end{array}$ & $\begin{array}{c}\text { Shallow } \\
(0.76)\end{array}$ & $0.521 \cdots$ \\
\hline & $\mathrm{Z}-\mathrm{Z}$ & Depth & $\begin{array}{l}\text { Deep } \\
(0.35)\end{array}$ & $\begin{array}{c}\text { Shallow } \\
(0.49)\end{array}$ & $0.141 \mathrm{~ns}$ \\
\hline & \multicolumn{5}{|l|}{ Depth } \\
\hline & Shallow & Bed type & $\begin{array}{c}Z-Z \\
(0.49)\end{array}$ & $\begin{array}{c}\mathrm{R}-\mathrm{Z} \\
(0.76)\end{array}$ & $0.267 \mathrm{~ns}$ \\
\hline & Deep & Bed type & $\begin{array}{c}R-Z \\
(0.24)\end{array}$ & $\begin{array}{c}Z-Z \\
(0.35)\end{array}$ & $0.113 \mathrm{~ns}$ \\
\hline
\end{tabular}

pling was initiated when high numbers of postlarvae were collected in nighttime plankton samples upriver, where the highest densities of postlarvae through 3rd instars were also caught in suction samples.

\section{Influence of plant species on later instar distributions}

Abundance of later instars ( $>3$ rd instar) did not differ by site along the river axis, but later instars were generally more abundant in Ruppia than Zostera. This distribution was related to seagrass species and not depth, since crabs were evenly distributed between shallow and deep Zostera beds, and may have resulted from habitat selection (Bell \& Westoby 1986), differential predation (Pile et al. 1996), or food availability.

Predation can play a major role in the abundance of certain instar stages but may be influenced by certain vegetational characteristics (e.g. shoot density) or prey characteristics (e.g. size) (Heck \& Thoman 1981, Pile et al. 1996, Schulman 1996). In 1995, Ruppia shoot densities were higher than those of Zostera, and 4th to 7 th instar abundances were positively correlated with Ruppia shoot density. Although Pile et al. (1996) showed that 5 th to 7 th instars gain a relative refuge from predation because of their size, their greater abundance in vegetation may reflect that these are the instars (i.e. sizes) that are balancing the relative values of vegetational refuge versus size refuge from predation.

The relationship between Ruppia beds, shoot density, and the densities of crabs greater than the 7 th instar, however, was not as clear. Within Ruppial Zostera beds, 8 th to 9 th instars were more abundant in Ruppia than in Zostera areas. Generally, juveniles greater than the 9th instar were more abundant in Ruppia/Zostera beds than in Zostera beds. However, these crab densities were not significantly related to shoot densities. The relationship between shoot density and crab density may break down when crabs reach the 8th instar, possibly because size-refuge from predation at these instar stages influences survival more than vegetational characteristics (Pile et al. 1996).

Ruppia and Zostera shoot densities change seasonally and in response to varying weather conditions (Orth \& Moore 1986). The summer of 1995 was unusually hot, with air temperatures above $32^{\circ} \mathrm{C}$ for over 20 consecutive days prior to sampling. Zostera defoliated considerably during this heat wave. Changes in seagrass density may lead to changes in habitat use by blue crabs: juvenile blue crabs may be more abundant in Zostera beds prior to yearly summer defoliation. In a recent study, blue crab postlarvae settled in higher 


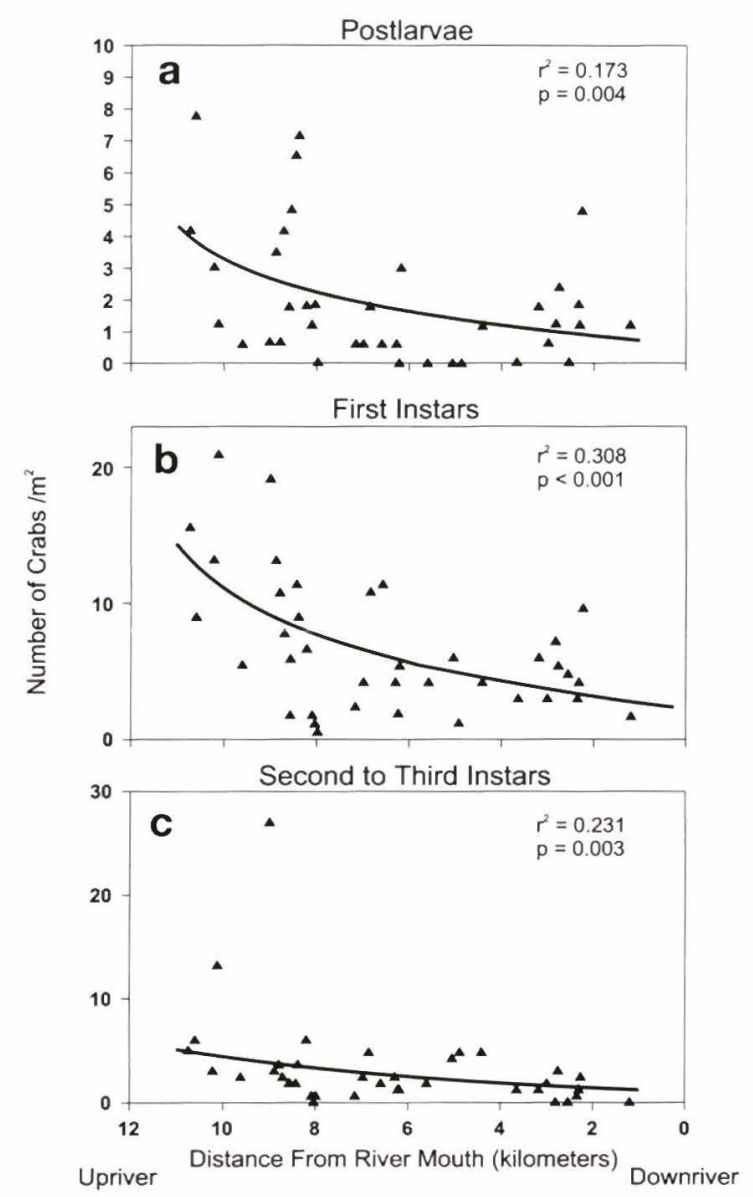

Fig. 7. Correlation between distance along the York River and number of postlarvae, first instars, and second to third instars in 1995. ( $\mathbf{\Lambda}$ ) Individual samples. Linearly transformed regression equations: (a) postlarvae $=14.73-3.47 \log ($ distance upriver) (regression, $\mathrm{r}^{2}=0.173, \mathrm{p}=0.004$ ). (b) 1 st instars $=$ $47.78-11.14 \log$ (distance upriver) (regression, $\mathrm{r}^{2}=0.308, \mathrm{p}<$ $0.001)$. (c) $\operatorname{Ln}(2 \mathrm{nd}$ to $3 \mathrm{rd}$ instars $)=1.78-0.000144$ (distance upriver) (regression, $\mathrm{r}^{2}=0.231, \mathrm{p}=0.003$ )

abundances on Spartina alterniflora than on R. maritima or Juncus roemarianus in August; in September, more postlarvae settled on Ruppia (Morgan et al. 1996). Ruppia may be a more important habitat during the late summer after Zostera defoliates. Similarly, vegetation die-back caused an increase in prawn abundance but a decrease in fish abundance in an Australian estuary (Halliday 1995).

\section{Nonsignificance of water depth}

In contrast to findings with other invertebrates (Ruiz et al. 1993, Platell \& Potter 1996), water depth did not determine abundance of any juvenile crab size classes. In this study, the effect of seagrass species may have

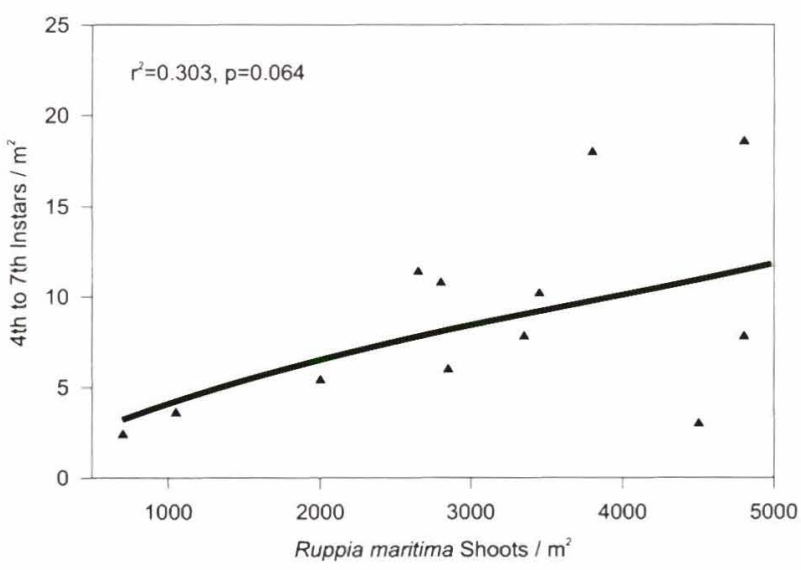

Fig. 8. Correlation between number of 4 th to 7 th instars and the number of Ruppia shoots in 1995. ( $\mathbf{\Delta}$ ) Individual samples. Linearly transformed regression equation: $\log (4$ th to 7 th instars) $=-0.233+0.652 \log$ (shoot number) (regression, $\mathrm{r}^{2}=$ $0.303, p=0.064$ )

overshadowed the effect of depth as a refuge. In a similar study, benthic invertebrates, including the polychaetes Ceratonereis aequisetis and Capitella capitata, and the gastropod Hydrococcus brazieri were significantly more abundant in shallow water $(<1.0 \mathrm{~m})$ than in deep water (2.0 to $2.5 \mathrm{~m}$ ). Ruppia megacarpa was also significantly more dense in shallow water and may have influenced species distributions by providing refuge and nutrition (Platell \& Potter 1996).

We propose the following model for the distribution of postlarvae and young juveniles of the blue crab in the York River. The abundance of postlarvae through 3 rd instars in a particular habitat is strongly influenced by larval supply and physical forces such as currents and winds, which could result in differential distribution along a river axis. Crabs greater than the 3rd instar are more strongly influenced by microhabitat features (e.g. seagrass species and density). Thus, the intensity and character of habitat selection by juvenile blue crabs appear to vary ontogenetically.

Acknowledgements. Without the generous support of many volunteers, this project would not have been feasible. We are extremely grateful to the following people who helped in the field: Jeff Bennett, Susan Bogardy, Buddy Bunting, Tom Chisholm, Gary Duff, Eric Farrar, Jamie Fishman, Elaina Haueber, Beth Hinchey, Nicole Keith, Guan Hong Lee, Tong Li, Ai Ning Loh, Sandy Merrill, Karen Metcalf, Star Miller, Jennifer Murray, Leah Nagey, Adele Pile, Kim Rilee, Alessandra Sagasti, Andrew Suntsov, Chandell Terwilliger, Craig Tobias, George Vadas, and Jacques van Montfrans. Eric Farrar was especially helpful with his boating and field expertise. Gary Duff also spent many days helping to sort samples. Shirley Crossley and Raymond Forrest kept boats and equipment organized and operating. We also thank Dave Wilcox, Gary Anderson, Leah Nagey, Judy Nowak, and Kay Stubblefield for help with computers and graphics. Jacques van 
Montfrans, Carl Friedrichs, and Mark Patterson provided helpful comments on the manuscript. We gratefully acknowledge support for this research sponsored in part by NOAA, Office of Sea Grant, U.S. Dept. of Commerce (Grant No. NA90AA-D-SG-045), Virginia's Chesapeake Bay Submerged Aquatic Vegetation Initiative to the Virginia Institute of Marine Science, and a private grant from the Allied-Signal Foundation (to R.J.O.). This study is contribution No. 2248 from the School of Marine Science, Virginia Institute of Marine Science, College of William and Mary.

\section{LITERATURE CITED}

Agresti A (1990) Categorical data analysis. John Wiley and Sons, New York

Bell JD, Westoby M (1986) Variation in seagrass height and density over a wide spatial scale: effects on common fish and decapods. J Exp Mar Biol Ecol 104:275-295

Bronmark C (1985) Interactions between macrophytes, epiphytes and herbivores: an experimental approach. Oikos $45: 26-30$

Butman CA (1987) Larval settlement of soft-sediment invertebrates: the spatial scales of pattern explained by active habitat selection and the emerging role of hydrodynamical processes. Oceanogr Mar Biol Annu Rev 25:113-165

Childress MJ, Herrnkind WF (1994) The behavior of juvenile Caribbean spiny lobster in Florida Bay: seasonality, ontogeny and sociality. Bull Mar Sci 54(3):819-827

Day EA, Lawton P (1988) Mud crab (Crustacea: Brachyura: Xanthidae) substrate preference and activity. J Shellfish Res $7(3): 421-426$

den Hartog C (1970) The sea-grasses of the world. North-Holland Publishing Company, Amsterdam

den Hartog C (1977) Structure, function, and classification in seagrass communities. In: McRoy CP, Helfferich C (eds) Seagrass ecosystems-a scientific perspective. Marcel Dekker, New York, p 89-121

Dittel AI, Hines AH, Ruiz GM, Ruffin KK (1995) Effects of shallow water refuge on behavior and density-dependent mortality of juvenile blue crabs in Chesapeake Bay. Bull Mar Sci 57 (3):902-916

Duarte CM (1991) Seagrass depth limits. Aquat Bot 40: $363-377$

Eckman JE (1983) Hydrodynamic processes affecting benthic recruitment. Limnol Oceanogr 28(2):241-257

Eckman JE, Nowell ARM (1984) Boundary skin friction and sediment transport about an animal-tube mimic. Sedimentology 31:851-862

Eggleston DB, Armstrong DA (1995) Pre- and post-settlement determinants of estuarine dungeness crab recruitment. Ecol Monogr 65(2):193-216

Elliott JM (1971) Some methods for the statistical analysis of samples of benthic invertebrates. Freshwater Biol Assoc, Sci Pub No. 25

Epifanio CE (1988) Transport of invertebrate larvae between estuaries and the continental shelf. Trans Am Fish Soc Symp Ser 3:104-114

Fernandez M, Armstrong D, Iribarne O (1993) First cohort of young-of-the-year Dungeness crab, Cancer magister, reduces abundance of subsequent cohorts in intertidal shell habitat. Can J Fish Aquat Sci 50:2100-2105

Fonseca MS, Fisher JS (1986) A comparison of canopy friction and sediment movement between four species of seagrass with reference to their ecology and restoration. Mar Ecol Prog Ser 29:15-22
Forward RB Jr, Frankel DAZ, Rittschof D (1994) Molting of megalopae from the blue crab Callinectes sapidus: effects of offshore and estuarine cues. Mar Ecol Prog Ser 113: 55-59

Goodrich D, van Montfrans J, Orth RJ (1989) Blue crab megalopal influx to Chesapeake Bay: evidence for a wind-driven mechanism. Estuar Coast Shelf Sci 29:247-260

Hacker SD, Steneck RS (1990) Habitat architecture and the abundance and body-size-dependent habitat selection of a phytal amphipod. Ecology 71(6):2269-2285

Halliday IA (1995) Influence of natural fluctuations in seagrass cover on commercial prawn nursery grounds in a subtropical estuary. Mar Freshw Res 46:1121-2105

Heck KL, Crowder LB (1991) Habitat structure and predatorprey interactions in vegetated aquatic systems. In: Bell S, McCoy ED, Mushinsky HR (eds) Habitat structure: the physical arrangement of objects in space. Chapman and Hall, New York, p 281-299

Heck KL, Thoman TA (1981) Experiments on predator-prey interactions in vegetated aquatic habitats. J Exp Mar Biol Ecol 53:125-134

Heck KL, Able KW, Roman CT, Fahay MP (1995) Composition, abundance, biomass, and production of macrofauna in a New England estuary: comparisons among eelgrass meadows and other nursery habitats. Estuaries 18(2): 379-389

Herrnkind WF, Butler MJ IV (1986) Factors regulating postlarval settlement and juvenile microhabitat use by spiny lobsters Panulirus argus. Mar Ecol Prog Ser 34:23-30

Humphries P (1996) Aquatic macrophytes, macroinvertebrate associations and water levels in a lowland Tasmanian river. Hydrobiologia 321:219-233

Kikuchi T, Peres JM (1977) Consumer ecology of seagrass beds. In: McRoy CP, Helfferich C (eds) Seagrass ecosystems: a scientific perspective. Marcel Dekker, New York, p 147-193

Lipcius RN, Olmi EJ III, van Montfrans J (1990) Planktonic availability, molt stage and settlement of blue crab postlarvae. Mar Ecol Prog Ser 58:235-242

Lipcius RN, Eggleston DB, Miller DL, Luhrs TC (1998) The habitat-survival function for Caribbean spiny lobster: an inverted size effect and non-linearity in mixed algal and seagrass habitats. Mar Freshw Res 49:807-816

Loneragan NR, Kenyon RA, Haywood MDE, Staples DJ (1994) Population dynamics of juvenile tiger prawns (Penaeus esculentus and P. semisulcatus) in seagrass habitats of the western Gulf of Carpentaria, Australia. Mar Biol 119:133-143

Lonzarich DG, Quinn TP (1995) Experimental evidence for the effect of depth and structure on the distribution, growth, and survival of stream fishes. Can J Zool 73: 2223-2230

Love SD, Bailey RC (1992) Community development of epilithic invertebrates in streams: independent and interactive effects of substratum properties. Can $\mathrm{J}$ Zool 70 : 1976-1983

Luckenbach M, Orth RJ (1992) Swimming velocities and behavior of blue crab (Callinectes sapidus Rathbun) megalopae in still and flowing water. Estuaries 14:186-192

Marinelli RL, Coull BC (1987) Structural complexity and juvenile fish predation on meiobenthos: an experimental approach. J Exp Mar Biol Ecol 108:67-81

Miltner RJ, Ross SW, Posey MH (1995) Influence of food and predation on the depth distribution of juvenile spot (Leiostomus xanthurus) in tidal nurseries. Can J Fish Aquat Sci 52:971-982

Moksnes PO, Lipcius RN, Pihl L, van Montfrans J (1997) Can- 
nibal-prey dynamics in young juveniles and postlarvae of the blue crab. J Exp Mar Biol Ecol 215:157-187

Morgan SG, Zimmer-Faust RK, Heck KL, Coen LD (1996) Population regulation of blue crabs Callinectes sapidus in the northern Gulf of Mexico: postlarval supply. Mar Ecol Prog Ser 133:73-88

Olmi EJ III (1994) Vertical migration of blue crab Callinectes sapidus megalopae: implications for transport in estuaries. Mar Ecol Prog Ser 113:39-54

Olmi EJ III, van Montfrans J, Lipcius RN, Orth RJ, Sadler PW (1990) Variation in planktonic availability and settlement of blue crab megalopae in the York River, Virginia. Bull Mar Sci 46(1):230-243

Orth RJ (1977) The importance of sediment stability in seagrass communities. In: Coull BC (ed) Ecology of marine benthos. University of South Carolina Press, Columbia, p 281-300

Orth RJ (1992) A perspective on plant-animal interactions in seagrasses: physical and biological determinants influencing plant and animal abundance. In: John DM, Hawkins SJ, Price JH (eds) Plant-animal interactions in the marine benthos, special vol no. 46. Clarendon Press, Oxford, p $147-164$

Orth RJ, Moore KA (1986) Seasonal and year-to-year variations in the growth of Zostera marina L. (eelgrass) in the lower Chesapeake Bay. Aquat Bot 24:335-341

Orth RJ, Moore KA (1988) Distribution of Zostera marina L. and Ruppia maritima L. Sensu lato along depth gradients in the lower Chesapeake Bay, USA. Aquat Bot 32:291- 305

Orth RJ, van Montfrans J (1987) Utilization of a seagrass meadow and tidal marsh creek by blue crabs Callinectes sapidus. I. Seasonal and annual variations in abundance with emphasis on post-settlement juveniles. Mar Ecol Prog Ser 41:283-294

Orth RJ, Heck KL Jr, van Montfrans J (1984) Faunal communities in seagrass beds: a review of the influence of plant structure and prey characteristics on predator-prey relationships. Estuaries 7:339-350

Orth RJ, van Montfrans J, Lipcius RN, Metcalf KS (1996) Utilization of seagrass habitat by the blue crab, Callinectes sapidus Rathbun, in Chesapeake Bay: a review. In: Kuo J, Phillips RC, Walker DI, Kirkman H (eds) Seagrass biology: proceedings of an international workshop, Western Australia. Western Australian Museum, Perth, Western Australia, p 213-214

Pearson ES, Hartley HO (1966) Biometrika tables for statisticians, 3rd edn. Cambridge University Press, Cambridge

Perkins-Visser E, Wolcott TG, Wolcott DL (1996) Nursery role of seagrass beds: enhanced growth of juvenile blue crabs (Callinectes sapidus Rathbun). J Exp Mar Biol Ecol 198: $155-173$

Pile AJ, Lipcius RN, van Montfrans J, Orth RJ (1996) Densitydependent settler-recruit-juvenile relationships in blue crabs. Ecol Monogr 66(3):277-300

Platell ME, Potter IC (1996) Influence of water depth, season, habitat and estuary location on the macrobenthic fauna of a seasonally closed estuary. J Mar Biol Assoc UK 76:1-21

Ray M, Stoner AW (1995) Growth, survivorship, and habitat choice in a newly settled seagrass gastropod, Strombus gigas. Mar Ecol Prog Ser 123:83-94

Richards RA (1992) Habitat selection and predator avoidance:

Editorial responsibility: Kenneth Heck (Contributing Editor), Dauphin Island, Alabama, USA ontogenetic shifts in habitat use by the Jonah crab Cancer borealis (Stimpson). J Exp Mar Biol Ecol 156:187-197

Roughgarden J, Gaines S, Possingham H (1988) Recruitment dynamics in complex life cycles. Science 241:1460-1466

Ruiz GM, Hines AH, Posey MH (1993) Shallow water as a refuge habitat for fish and crustaceans in non-vegetated estuaries: an example from Chesapeake Bay. Mar Ecol Prog Ser 99:1-16

Ryer C (1987) Studies of pipefish foraging in simulated seagrass habitats. $\mathrm{PhD}$ dissertation, The College of William and Mary, Gloucester Point

Schneider F, Mann K (1991a) Species specific relationships of invertebrates to vegetation in a seagrass bed. II. Experiments on the importance of macrophyte shape, epiphyte cover and predation. J Exp Mar Biol Ecol 145:119-139

Schneider F, Mann K (1991b) Species specific relationships of invertebrates to vegetation in a seagrass bed. I. Correlational studies. J Exp Mar Biol Ecol 145:101-117

Schulman JL (1996) Habitat complexity as a determinant of juvenile blue crab survival. MS thesis, The College of William and Mary, Gloucester Point

Stoner AW (1980) Perception and choice of substratum by epifaunal amphipods associated with seagrasses. Mar Ecol Prog Ser 3:105-111

Stoner AW (1983) Distributional ecology of amphipods and Tanaidaceans associated with three seagrass species. J Crustac Biol 3(4):505-518

Stoner AW, Lewis FG III (1985) The influence of quantitative and qualitative aspects of habitat complexity in tropical sea-grass meadows. J Exp Mar Biol Ecol 94:19-40

Tupper M, Boutilier RG (1995) Effects of habitat on settlement, growth, and postsettlement survival of Atlantic cod (Gadus morhua). Can J Fish Aquat Sci 52:1834-1841

van Montfrans J, Peery C, Orth RJ (1990) Daily, monthly and annual settlement patterns by Callinectes sapidus and Neopanope sayi megalopae on artificial collectors deployed in the York River, Virginia: 1985-1988. Bull Mar Sci 46(1):214-229

van Montfrans J, Epifanio CE, Knott DM, Lipcius RN, Mense DJ, Metcalf KS, Olmi EJ III, Orth RJ, Posey MH, Wenner EL, West TL (1995) Settlement of blue crab postlarvae in western North Atlantic estuaries. Bull Mar Sci 57(3): $834-854$

Virnstein RW, Howard RK (1987) Motile epifauna of marine macrophytes in the Indian River lagoon, Florida. I. Comparisons among three species of seagrasses from adjacent beds. Bull Mar Sci 41(1):1-12

Williams AH, Coen LD, Stoelting MS (1990) Seasonal abundance, distribution, and habitat selection of juvenile Callinectes sapidus (Rathbun) in the northern Gulf of Mexico. J Exp Mar Biol Ecol 137:165-183

Wilson KA, Able KW, Heck KL Jr (1990) Predation rates on juvenile blue crabs in estuarine nursery habitats: evidence for the importance of macroalgae (Ulva lactuca). Mar Ecol Prog Ser 58:243-251

Worthington DG, Ferrell DJ, McNeill SE, Bell JD (1992) Effects of the shoot density of seagrass on fish and decapods: are correlations evident over larger spatial scales? Mar Biol 112:139-146

Zar JH (1984) Biostatistical analysis. Prentice-Hall, Englewood Cliffs, NJ

Submitted: June 11, 1997; Accepted: March 18, 1999

Proofs received from author(s): August 31, 1999 